\title{
'Florilush': A Bunch Grape Rootstock for Florida
}

\author{
J.A. Mortensen ${ }^{1}$ J.W. Harris ${ }^{2}$, and D.L. Hopkins ${ }^{3}$ \\ Central Florida Research and Education Center, University of Florida, 5336 \\ University Avenue, Leesburg, FL 34748
}

Additional index words. Vitis, fruit breeding, disease resistance

'Florilush' grape (Vitis champini Planch. V. aestivalis Michx., V. labrusca L.) (Rogers and Mortensen, 1979) is being released by the Univ. of Florida as a bunch grape rootstock because of its superiority to rootstocks currently used in Florida. 'Florilush' has a higher percentage of successful grafts and a lower tendency to produce sprouts below the graft union than 'Dog Ridge'. It also enhances vigor in young scions and has a higher tolerance to grape root borer than 'Tampa'. The name 'Florilush' signifies healthy, lush growth that is promoted in Florida's deep, sandy soils and hot, humid climate.

\section{Origin}

'Florilush', tested as Fla. CD9-81, originated from a 1978 cross of 'Dog Ridge' $x$ 'Tampa'. 'Dog Ridge' is a vigorous rootstock well suited for deep, sandy soils (Mortensen, 1972), and 'Tampa' is a medium-vigor rootstock that does well in low areas and in deep, sandy soils (Mortensen and Stover, 1982). The original seedling of 'Florilush' was planted in the Leesburg vineyard in 1979. 'Florilush' was first selected in 1984 because of its outstanding vigor and health in comparison with other seedlings in the rootstock program.

\section{Description}

When not grafted, 'Florilush' develops a large trunk and cane framework with vigorous growth. Internodes range from 9 to $16 \mathrm{~cm}$ in length, and mature leaves average $15 \mathrm{~cm}$ long and $18 \mathrm{~cm}$ wide. Upper leaf surfaces are dark green and shiny, lower leaf surfaces are light green, and leaf edges are coarsely serrated. Leaves, petioles, and stems are slightly pubescent. Anthocyanin pigmentation occurs in stems, petioles, and leaves, becoming more apparent with tissue maturation. Tendrils are uninterrupted. Healthy shoot tips are common

Received for publication 22 Feb. 1994. Accepted for publication 21 June 1994. University of Florida Agricultural Experiment Station Journal series paper no. R-03679. The cost of publishing this paper was defrayed in part by the payment of page charges. Under postal regulations, this paper therefore must be hereby marked advertisement solely to indicate this fact.

${ }^{1}$ Professor Emeritus.

${ }^{2}$ Senior Lab Technician.

${ }^{3}$ Professor of Plant Pathology. even in the late fall when most cultivars suffer dieback. Flowers are pistillate, and fruit are small, purple, and unmarketable.

Dormant cuttings of 'Florilush' root readily in containers or field nurseries, up to $100 \%$ but not $<70 \%$. When bench-grafted, 'Florilush' had $>90 \%$ successful unions and produced greater scion vigor in 'Orlando Seedless' than did 'Tampa' (Table 1).

Less root damage from grape root borer has been observed in vineyard plantings than with 'Dog Ridge' or 'Tampa' (Webb and Mortensen, 1990). 'Florilush' was tested for grape root borer resistance by inoculatiing potted plants. Five-month-old plants were infested with 15 root borer eggs per pot. Vines were destructively sampled and data collected 14 months later. There were significantly fewer root borer tunnels per root on 'Florilush' than on 'Tampa' (Table 2).

'Florilush' is resistant to Pierce's disease (Xylella fastidiosa Wells et al.) (Mortensen et al., 1977), anthracnose [Elsinoe ampelina (de Bary) Shear], downy mildew [Plasmopara viticola (B \& C) Berl. \& de T.], powdery were destructively sampled. root borer $(\mathrm{GRB}){ }^{.}$ test by Webb and Mortensen in 1988-89).

'Vigor rating: $0=$ dead, $5=$ highly vigorous.

"Trunk damage: $0=$ no damage, $5=$ severe damage. mildew [Unicinula necator (Schw.) Burr.], and Isariopsis leaf blight. 'Florilush' has a high tolerance to various nematodes that has been demonstrated by $100 \%$ replant survival in the vineyard and by planting into heavily infested nematode areas without general symptoms. Principal parasitic nematodes in replant sites were Criconemoides, Belonolaimus, Meloidogyne, and Trichodorus.

'Florilush' promotes good vigor in mature vines grafted onto it (Table 1). Replicated yield data are not available, but fruit set and cluster size and shape were excellent in mature 'Orlando Seedless' vines on 'Florilush' rootstock. Although 'Florilush' has less tendency to sprout below graft unions than its parent 'Dog Ridge', cuttings should be debudded before planting to reduce root sprouts further. 'Florilush' is adapted to well-drained soils of Florida. To our knowledge, no useful data exist as to how it will perform on bedded soils in flatwood areas.

\section{Summary}

The principal advantages of 'Florilush' grape rootstock are disease resistance, nematode resistance, higher tolerance to grape root borer, fewer rootstock sprouts, and adaptability to bench grafting and field grafting with a high percentage of graft unions. It is recommended as a rootstock for less vigorous cultivars that do poorly on their own roots (e.g., 'Conquistador', 'Stover', 'Orlando Seedless'). 'Florilush' propagates readily from hardwood cuttings (dormant) taken in late December or January. With a high percentage of successful bench graft unions, 'Florilush' is well adapted for commercial nursery operations.

Table 1. Plant performance characteristics 3 months after bench grafting, and scion vigor after 4 years in the vineyard for 'Orlando Seedless' scion on 'Florilush' compared to 'Dog Ridge' and 'Tampa'.

\begin{tabular}{lccccc}
\hline \hline & $\begin{array}{c}\text { Successful } \\
\text { graft } \\
\text { unions } \\
(\%)^{\mathrm{z}}\end{array}$ & $\begin{array}{c}\text { Scion } \\
\text { vigor }^{\mathrm{z}, \mathrm{y}}\end{array}$ & $\begin{array}{c}\text { Scion } \\
\text { growth } \\
\mathrm{wt}(\mathrm{g})^{\mathrm{z}}\end{array}$ & $\begin{array}{c}\text { Rootstock } \\
\text { root } \\
\mathrm{wt}(\mathrm{g})^{\mathrm{z}}\end{array}$ & $\begin{array}{c}\text { Mature } \\
\text { scion } \\
\text { vigor }^{\mathrm{y}}\end{array}$ \\
Rootstock & 92.0 & $3.7 \mathrm{a}$ & 41.4 & 17.7 & $4.3 \mathrm{a}$ \\
\hline Florilush & 64.0 & $3.5 \mathrm{a}$ & 36.9 & 19.8 & $3.9 \mathrm{a}$ \\
Dog Ridge & 96.0 & $2.1 \mathrm{~b}$ & 20.8 & 7.6 & $4.0 \mathrm{a}$ \\
Tampa & & &
\end{tabular}

${ }^{2}$ Data were taken from 25 grafts with each rootstock 3 months after bench grafting in Spring 1988. Plants

${ }^{y}$ Scion vigor: $0=$ dead, $5=$ highly vigorous. The mature vine vigor combines data from four replications of three vines each in 1988-91. Mean separation within columns by Duncan's multiple range test, $P \leq 0.05$.

Table 2. Plant performance of 'Florilush', 'Dog Ridge', and 'Tampa' in containers inoculated with grape

\begin{tabular}{lcccccc}
\hline \hline Cultivar & $\begin{array}{c}\text { Vigor } \\
\text { rating }^{\mathrm{y}}\end{array}$ & $\begin{array}{c}\text { Roots/ } \\
\text { vine }^{\mathrm{x}}\end{array}$ & $\begin{array}{c}\text { Trunk } \\
\text { damage }^{\mathrm{w}}\end{array}$ & $\begin{array}{c}\text { Tunnels/ } \\
\text { root }^{\mathrm{x}}\end{array}$ & $\begin{array}{c}\text { GRB } \\
\text { larvae }^{\mathrm{x}}\end{array}$ & $\begin{array}{c}\text { Plants } \\
\text { killed } \\
(\%)\end{array}$ \\
\hline Florilush & 3.8 & $15.0 \mathrm{a}$ & 3.8 & $0.4 \mathrm{a}$ & $3.3 \mathrm{a}$ & 25.0 \\
Dog Ridge & 3.8 & $18.8 \mathrm{a}$ & 5.0 & $0.8 \mathrm{ab}$ & $1.5 \mathrm{a}$ & 25.0 \\
Tampa & 1.3 & $15.5 \mathrm{a}$ & 5.0 & $1.0 \mathrm{~b}$ & $0.5 \mathrm{a}$ & 75.0 \\
\hline
\end{tabular}

${ }^{2}$ Vigor rating, roots per vine, trunk damage rating, tunnels per root, number of GRB larvae found in containers at the end of experiment, and percentage of plants killed by GRB larvae (data from a screenhouse

'Mean separation within columns by Tukey's Studentized range test, $P \leq 0.10$. 


\section{Cultivar \& Germplasm Releases}

\section{Availability}

Direct inquiries regarding the availability of 'Florilush' to Florida Foundation Seed Producers, P.O. Box 309, Greenwood, FL 32443. A current list of nurseries selling Floridarecommended grape cultivars may be obtained from most Institute of Food and Agricultural Sciences County Extension Service Offices.

\section{Literature Cited}

Mortensen, J.A. 1972. Dog Ridge, a superior grape rootstock for Florida. Proc. Fla. State Hort. Soc. 85:275-279.

Mortensen, J.A. and L.H. Stover. 1982. 'Tampa' grape rootstock. HortScience 17:273-274.

Mortensen, J.A., L.H. Stover, and C.F. Balerdi. 1977. Sources of resistance to Pierce's dis- ease in Vitis. J. Amer. Soc. Hort. Sci. 102:695697.

Rogers, D.J. and J.A. Mortensen. 1979. The native grape species of Florida. Proc. Fla. State Hort. Soc. 92:286-289.

Webb, S.E. and J.A. Mortensen. 1990. Evaluation of bunch grape rootstocks and muscadine varieties for resistance to grape root borer. Proc. Fla. State Hort. Soc. 103:310-313. 